\title{
Thucydides and the Historiography of the Future
}

I shall be content if those wishing to know the truth about the things which happened, and which, people being as they are, will happen again in the same or similar manner, will judge my work to be useful.

Thucydides 1.22

Knowledge of the past is treasured at all times only in the service of the future and the present, not for the weakening of the present or the uprooting of a vigorous future.

Friedrich Nietzsche, 'Zum Nutzen und Nachtheil der Historie für das Leben’ (1874), 271.

What is, or should be, the goal of historical research and writing? How can knowledge of the past be made useful or productive? As the title suggests, the aim of this chapter is to develop a dialogue between Thucydides and Nietzsche, or at any rate to juxtapose their ideas and explore the consequences, in relation to historiography and the possible meanings of the past. Nietzsche's admiration for Thucydides is now a well-established element of Thucydidean reception, above all when he presented him as the perfect embodiment of 'realist culture' in opposition to the deception and cowardice of Platonism, an interpretation whose influence on twentieth-century readings is increasingly recognised. ${ }^{1}$ Here, however, I want to focus on a much earlier piece in which Nietzsche nowhere mentioned Thucydides, but which raises important questions about the nature, purpose and reception of Thucydides' work, and where, I suggest, his presence can be surmised throughout: the second Untimely Meditation from 1874, 'On the uses and disadvantages of history for life'.

There are three dimensions to the dialogue that I want to establish. The first and most straightforward involves reading key aspects of Thucydides' work through the framework of ideas which Nietzsche developed to characterise historiography, and especially of his own age; above all, considering how far Thucydidean historiography conforms to one or other of the different categories of historical thinking identified in the essay. ${ }^{2}$ This is an exercise in self-conscious

1 Nietzsche 1889, 156. On Nietzsche, Thucydides and 'realism' see e.g. Zumbrunnen 2015 and Morley 2018.

2 For a more conventional reading of Thucydidean historiography, see Greenwood 2006. 
anachronism; we can read Thucydides in Nietzschean terms, without for a moment implying that this was his deliberate intent. The enterprise can to some extent be defended on the grounds that Nietzsche identified parallels between the saturation of his own age with history and the fact that the Greeks were the first to experience a fully historical culture; we might then might surmise the existence of parallels in ancient and modern desire for and modes of engaging with the past, even if the end results were (as he argued) quite different. ${ }^{3}$ However, it seems more likely that the contrasts between Nietzsche's account of modern historical drives and Thucydides' ideas (or at least a plausible reading of them) will be most illuminating - and that this is the intended outcome of his reflections, rather than revealing flaws in his supposedly would-be universal framework of interpretation.

Secondly, we can reverse the perspective, and evaluate Nietzsche's ideas in terms of their resemblance to Thucydides' claims about how and why he wrote his work. This includes the possibility that Nietzsche's ideas were significantly influenced by his reading of the Greek text, which he had studied, together with a range of relevant contemporary scholarship including Wilhelm Roscher's Leben, Werk und Zeitalter des Thukydides and Friedrich Creuzer's Die historische Kunst der Griechen, in the late 1860s, while developing an outline for a new course on the beginnings of Greek historiography. ${ }^{4}$ Thucydides can become a Nietzschean only in retrospect, whereas Nietzsche might indeed be a thorough-going Thucydidean, and not only on those occasions in his later works where he chose to present himself as such. Of course, in the absence of any direct references or citations of Thucydides in the essay, this can only be a matter of speculation on the basis of identifying possible parallels in thought and expression - but some of these are suggestive, as seen in the emphasis that both authors place on historiography being concerned with more than just knowledge of the past as an end in itself.

The third element of this brief discussion applies Nietzsche's historiographical framework to contemporary receptions of Thucydides and debates about his significance. As James Porter has observed in the case of the other philological writings, Nietzsche's accounts of antiquity generally tell us far more about his own ideas about modernity than they do about the ancient past, and are better understood as a form of cultural critique, including the critique of how others imagine and represent classical antiquity in their own image. ${ }^{5}$ We might imagine,

3 Nietzsche 1874, 333-4; foreshadowed at 271.

4 Hennis 2003, 36; Emden 2008, 49.

5 Porter 2000, 5. 
therefore, that he would be at least as concerned with contemporary readers' (mis)readings and (mis)appropriations of Thucydides as with his own ideas about Thucydides' work - but in any case, his claims about the different ways in which the past is interpreted and represented can be applied to modern accounts of Thucydides, regardless of whether that was Nietzsche's intention, in order to explore Thucydidean reception from a new perspective.

\section{Monuments, Data, Judgements}

Nietzsche's essay opens by establishing that the historical sense is an essential part of being human. The ignorance of animals who live contentedly fettered to the moment may seem enviable, a kind of lost paradise or return to childhood, as it brings happiness at least in the negative sense of not being tormented by thoughts of the past or fear of the future, but it is beyond human reach except through the ultimate forgetting of death. But it remains the case, Nietzsche argued, that a certain amount of forgetting is essential for life; 'a man who wanted to feel everything historically through and through would be like someone who was forcibly deprived of sleep', and there is a degree of insomnia, of constant reflection and of historical sense which is harmful and ultimately fatal to ordinary beings. ${ }^{6}$ One might, through an excess of history, attain a suprahistorical perspective, in which one recognises the pointlessness of existence, the blindness and injustice on which all human action depends, and sees that there is no real difference between past and present - but that perspective too is hostile to life, since it destroys any temptation to go on living or take part in events. What matters for ordinary people is the balance between knowing and forgetting, between the historical and the unhistorical; accepting historical knowledge as part of being human, while staying on the right side of the boundary where an excess of history allows the past to become 'the gravedigger of the present'. ${ }^{7}$ If history and the historical sense are unavoidable, especially for Europeans, they should at least be employed better for the purpose of life. ${ }^{8}$

6 Nietzsche 1874, 250.

7 Ibid., 251.

8 Ibid., 256-7. 
Nietzsche identified three ways in which life needs the service of history, pertaining to three different aspects of human existence: acting and striving, preserving and revering, and suffering and in need of deliverance. ${ }^{9}$ This gives rise to a trio of historical varieties, the monumental, the antiquarian and the critical ideas which apply equally to the motives of production and appetites for consumption of history. Monumental history desires and provides models, teachers and comforters. It shows that greatness was once possible and so may be possible again, banishing doubt and resignation in the face of the present, and it acts as a stimulus, presenting the past as worthy of imitation. Antiquarian history seeks and offers comfort and certainty, 'the contentment of the tree in its roots', knowing and revering one's origins and the origins of the community or nation. Critical history, in contrast to both these approaches and in active opposition to them, seeks to identify those parts of the past that weigh us down, so that they can be scrupulously examined and finally condemned. Each of these varieties of history serves the cause of life; each of them, Nietzsche argued, can easily be taken to excess and lose touch with the true purpose of engaging with the past, and so become a danger.

How does Thucydides' work compare with these ideas? Certainly he did not share Nietzsche's concern with the problems of the excess of the historical; rather, he disparaged hoi polloi who fail to enquire properly into the past but simply accept the first story they hear (1.20), and writers who narrate past events with a view to entertainment rather than truth (1.21), both of which might be regarded as a necessary (or at least desirable) form of 'forgetting'. However, Thucydides' project was certainly not study of the past for its own sake. Rather, his stated criterion for the success of his history was that a reader, or the right kind of reader, should find it useful for understanding present and future events - exactly as Nietzsche, perhaps deliberately echoing him, had insisted: 'Knowledge of the past is treasured at all times only in the service of the future and the present'. ${ }^{10}$ Far more almost any historian who has come after him, Thucydides devoted himself and his work to the service of present and future Life rather than the dead past.

Modern interpreters of Thucydides have argued extensively about how Thucydides intended his readers to find the work useful - that is, what kinds of knowledge or understanding they should draw from it, and how (or whether) they should put it into action. ${ }^{11}$ Nietzsche's template of the three kinds of history offers

\footnotetext{
9 Ibid., 258.

10 Ibid., 271.

11 Morley 2014, 139-64.
} 
a different perspective on this question - if only in negative terms. There is little in Thucydides' account that matches the 'monumental' conception - that seems far closer to Herodotus' stated goal in writing, 'in order that in this way the memory of the past may not be blotted out from among men by time, and that great and marvellous deeds done by Greeks and foreigners and especially the reason why they warred against each other may not lack renown' (1.1.0). Thucydides explicitly criticised the most prominent example of a monumental conception in classical Athens, the story of the Tyrannicides, by pointing out the extent to which its inspirational effect depended on the distortion of the past. Further, while less explicitly targeted at versions of past events intended to inspire and stimulate people, his critique of the reasons why other accounts of the past cannot be trusted - the tendency to project present assumptions back onto the past, as in the case of Mycenae (1.10); the influence of partiality, forgetfulness, and romanticism on people's accounts, and a preference for harmony and the illusion of completeness over harsh complexity (1.22) - runs in parallel with Nietzsche's criticism of the monumental approach: 'How much difference must be overlooked, if it is to have that powerful effect, how violently must the individuality of the past be squeezed into a general form, and all its sharp corners and outlines broken off for the sake of conformity' ${ }^{12}$ Finally, we might simply note how little of Thucydides' account offers heroic examples for celebration or imitation - one might see here an echo of one of Dionysius of Halicarnassus' complaints about his unedifying and unworthy depiction of the Athenians at Melos (Thucydides 38-40) - unless one breaks the narrative apart and discards the awkward elements, in order to establish Pericles as a model leader. The Thucydidean past is offered not as an inspiration but as an awful warning from which we should learn.

An insistence on the need for accuracy, even at the expense of good writing, entertainment or improving moral purpose, might seem to take Thucydides closer to Nietzsche's conception antiquarian history. However, as noted above, his work was certainly not dedicated to chronicling past events for their own sake - let alone a 'a restless scrabbling together of everything that has ever existed' - and as critics since Dionysius have noted, his account is neither complete nor straightforward, but uneven in its coverage and carefully constructed to offer Thucydides' version of the war rather than 'the' war. ${ }^{13}$ To this point we can add the striking resemblance of Nietzsche's antiquarian historian to the portrait of the 'historical artisan' offered by Wilhelm Roscher in his 1842 analysis of Thucydides

12 Nietzsche 1874, 261-2.

13 Ibid., 268. 
as a historical writer. ${ }^{14}$ Thucydides, Roscher claimed, is the true historian, developing a proper understanding of the past, in contrast to someone who 'remains confined in the simple collection of material... What the sources have to say, he passes reliably on to us; but never anything further or deeper'. ${ }^{15}$ Nietzsche's account of the antiquarian is more damning and dramatic, complaining of 'the stench of must and mould', the decay of any creative spirit and the insatiable thirst for antiquity, 'even the dust of bibliographical quisquilian', but it offers the same contrast between understanding the past and merely compiling and preserving it as an end in itself. ${ }^{16}$

This leaves us with critical historiography. On the one hand, if Nietzsche intended his trio of historical types to cover all eventualities, or we take them as such for the sake of argument, then this is the only viable option. Thucydides depicted a past that is indeed worthy of condemnation, as Nietzsche suggested: a succession of human errors, crimes, violence and injustice. On the other hand, there is the notable absence of actual condemnation in his text, the often-remarked absence of explicit authorial judgements. ${ }^{17}$ Of course Thucydides could present individuals and events as manifestly culpable without overtly condemning them in his own words (Cleon, and the fate of the Plataeans, are two examples that come to mind), but he does this without showing partisanship for either side. The overall spirit of his work seems to come closer to what Nietzsche identified as the main danger with critical history, the fact that all history is worthy of condemnation: 'because so it is with human affairs ['mit den menschlichen Dingen' echoes here of Thucydides' kata to anthropinon, 'the human thing', as the explanation for the repetitiveness of events?] that human violence and weakness are always powerful forces' ${ }^{18}$ The critical historian scrutinises, judges and condemns specific elements of the past, chosen for self-serving reasons, and if he realises that these judgements could apply to the whole past, to all his roots, he risks losing his own nature. Thucydides chose his subject matter because of its perceived importance; he revealed the threads of human violence, folly and weakness that run through it - and by implication through human history as a whole - but without losing himself. ${ }^{19}$

\footnotetext{
14 Morley 2012.

15 Roscher 1842, 11-12.

16 Nietzsche 1874, 268.

17 Cf. Morley 2014, 79-91 on accounts of Thucydides' impartiality.

18 Nietzsche 1874, 269.

19 Cf. Nietzsche 1875, 5[58]: 'Whoever does not understand how brutal and senseless history is will never understand the drive to make history intelligible.'
} 


\section{Transcending History}

It requires, Nietzsche argued, a great deal of strength to be able to live and to forget how far living and injustice are one and the same (echoes of Melos?). ${ }^{20}$ Those who serve life by judging and destroying the past are both dangerous and endangered, since it is never possible to escape the past completely: 'because we are the product of earlier generations, we also the product of their aberrations, passions and errors, and their crimes; it is not possible to free oneself completely from this chain. ${ }^{21}$ But Thucydides did not forget this, or pretend to transcend history; he is fully implicated in events - we see his own failure, treated as dispassionately as every other human misjudgement in his account - and the point of his endeavour was not to destroy the past but to learn from it. His recognition of 'the essential conditions of all events', the blindness and injustice of human action throughout history, comes close to Nietzsche's characterisation of the 'suprahistorical' perspective - but Thucydides did not fall into the temptation of despair or indifference in the face of this insight, since he continued to insist on the possibility of understanding as the basis for action in the present and future.

Instead, Thucydides better fits Nietzsche's idea of the historical man, which is presented as one possibility within the wider field of the suprahistorical:

\footnotetext{
We will call them the historical men: looking into the past drives them towards the future, fires up their courage to continue to hold on to life and kindles the hope that justice will still be done and that happiness lies behind the hill towards which they are advancing. These historical men believe that the meaning of existence will come more and more to light in the course of its process, they look backwards only so that, through consideration of the process so far, they can learn to understand the present and to desire the future more fiercely; they have no idea how unhistorically they think and act, despite all their history, nor how their preoccupation with history stands in the service, not of pure knowledge, but of life. ${ }^{22}$
}

It seems fair to suggest that Thucydides was conscious of acting unhistorically, stepping outside his own time and its assumptions in order to achieve a better understanding of events that could serve times to come. How far he retained hope in future justice and happiness remains uncertain - hope, after all, appears as 'a great comfort in danger' and the basis for numerous unwise decisions in his account. Nevertheless, the idea that meaning emerges in the process of history, the

20 Nietzsche 1874, 269.

21 Ibid., 270.

22 Ibid., 255. 
succession of events, perfectly sums up the basic method of his narrative; and he himself stated that the goal of the enterprise was usefulness, not pure knowledge. Such an attitude, Nietzsche argued, offers the possibility of overcoming rather than destroying the past, so that it no longer has power - but without thereby abandoning the world of history and action:

A historical phenomenon, purely and completely grasped and resolved into a phenomenon of knowledge, is, for whoever has grasped it, dead: for he has recognised in it the delusion, the injustice, the blind passion and in general the whole earthly darkening horizon of that phenomenon and at the same time the historical power within it. This power has now become, over him who knows, impotent; if perhaps not yet over him as a living being. ${ }^{23}$

If we imagine we see an image of Thucydides behind these ideas, then one implication is that he transcended not only the past but the category of 'historian'. As Nietzsche argued in his later comments, Thucydides grasped the truth about historical phenomena and about reality as a whole, he had the courage the face that truth rather than retreating into the comforting world of the ideal, and he sought to teach that understanding to others. In contrast to the moderns, Nietzsche claimed, the Greeks kept a tenacious hold of their unhistorical sense, and so avoided being destroyed by an excess of the past. ${ }^{24}$ Their culture was for centuries a chaos of foreign ideas, throwing their own traditions and roots into question is this an echo of Herodotean historiography, setting Greek history within a colourful maelstrom of foreign ideas and practices, and raising the unsettling idea that 'custom is king'? - but they held fast to the Delphic principle of knowing themselves and so organised the chaos..$^{25}$ Thucydides, praised by Nietzsche later as an exemplar of the healthy instincts of the pre-Socratic Greeks in their engagement with the world, is at the very least a representative of their mastery of history; his work might indeed be seen as one of the actual means by which they made sense of the chaos of events and understood their own nature. 'History can be endured only by strong personalities, it completely extinguishes the weak'. ${ }^{26}$

If the idea that Thucydides, or an idealised image of Thucydides, lies behind Nietzsche's critique of existing forms of history has any plausibility, then this might perhaps explain the vehemence of his attack on the idea of history as science that plays a central role in his discussion of modern historical culture in the

\footnotetext{
23 Ibid., 257.

24 Ibid., 273-4.

25 Ibid., 333.

26 Ibid., 283.
} 
second part of his essay. ${ }^{27}$ The demand that history should be a science, he argued, is modernity's fundamental error: 'Now life no longer reigns alone and sets limits on knowledge of the past; but all the barriers have been torn down, and everything that every was is dumped upon humanity'. ${ }^{28}$

Within the barrage of denunciations and laments about the state of modern German culture, we can identify three which bear directly on ideas of historiography. Firstly, 'history as science' has no sense of priorities or purpose, but knowledge of any kind is regarded as equally valuable: 'Knowledge, consumed in excess without any hunger and even contrary to one's needs' ${ }^{29}$ Secondly, the accumulation of such masses of information supports misconceived ideas about the superiority of the modern age - 'though this surfeit, an age develops the idea that it possesses the rarest of virtues, justice, to a higher degree than any other era' ${ }^{30}$ This goes hand in hand with the idea of historical objectivity, claimed as a distinctly modern achievement, which is in fact merely the naïve elevation of present-day knowledge and assumptions above every other mode of understanding, and which implies that the best person to study the past is someone to whom it means nothing. ${ }^{31}$ This characterisation overall bears a significant relationship to the decadent form of antiquarianism, the relentless accumulation of information about the past, so that modern culture loses any sense of its own nature but becomes a mere walking encyclopaedia. The distinctive modern claim is that the possession of such masses of data will automatically result in a better understanding of the world; and Nietzsche's greatest contempt is reserved for the nature of the knowledge that is produced by 'scientific history', general laws and principles about human behaviour.

\footnotetext{
It seems to me that such historians ... cease to teach as soon as they become general and then exhibit their sense of weakness in obscurities. In other sciences the generalisations are the most important thing, insofar as they contain the laws; but if such [historical] statements as those quoted want to be taken as laws, then it would be objected, that the work of the history-writer is a waste of time; because whatever truth remains in such sentences, after the removal of the dark unresolvable residue of which we spoke - that is already known and indeed trivial; because it will be obvious to anyone with the smallest amount of experience. $^{32}$
}

27 Discussed by Zumbrunnen 2002.

28 Nietzsche 1874, 271-2.

29 Ibid., 272.

30 Ibid., 279.

31 Ibid., 285-7, 293.

32 Ibid., 291-2. 
The relevance of Thucydides to this discussion is that, alone among pre-modern historians, he was claimed as a predecessor and inspiration by 19th-century proponents of 'Geschichte als Wissenschaft'. ${ }^{33}$ This reading relied primarily on his methodological statements at the beginning of Book 1, interpreting these as anticipations of modern precepts: critical analysis of evidence, objectivity (the new way of characterising what earlier readers had labelled 'impartiality') and the rejection of the idea of history as art, exemplified by his disparagement of works written as 'performance pieces'. In addition, however, some of these interpreters saw in Thucydides a new idea - or rather, a modern idea prefigured - of the kind of knowledge and understanding that history could offer, to match its rivals in the natural and social sciences.

He conceives of history not only as the new science of facts, but as a new science which, attaching itself to events, discerns in them the secret combinations, determines in them the laws and recognises in them the effects of intelligence. ${ }^{34}$

This offered a new way of understanding Thucydides' claim that his work would be useful: he had intended all along to identify through his study of past events the kinds of general principles of human nature that 19th-century historians now realised were required. The fact that his account contained no such statements of general principles - as Thomas Hobbes had observed two and a half centuries earlier - was of no great import.

From a Nietzschean perspective, such a reading was absurd: it reduced the depth and detail of Thucydides' account, and the underlying principle that understanding would develop in the course of events, to a clumsy vehicle for presenting banalities as universal laws. It disparaged the artistic elements of engagement with the past; not invariably, as Roscher's version of Thucydides as a proponent of scientific history insisted on the necessity of creative and literary skill to present scientific findings in an effective and persuasive manner, but the majority of 19th-century Thucydideans emphasised his disparagement of history written as entertainment and history exaggerated by the poets, and managed to overlook or negotiate the way around the obvious problem presented by his comments on the composition of the speeches. In terms of Nietzsche's typology of history, this modern reading of Thucydides epitomises the monumental, to be set alongside the 'antiquarianism' of philological readings: Thucydides is claimed as a heroic predecessor, and his example is offered for imitation and reverence -

33 Morley 2014, 59-69. Zumbrunnen 2002 discusses this tradition of Thucydidean reception, but focuses solely on 20th-century readings rather than those contemporary with Nietzsche.

34 Girard 1860, 11. I have not been able to establish whether Nietzsche knew of Girard's essay. 
but at the expense of distorting or even destroying the reality of the past, knocking off its rough edges (that is, elements of Thucydidean historiography that do not fit or even contradict modern assumptions). Modern Thucydideans might, perhaps, experience the anxiety of being epigones, and of being unable to match the greatness of past achievements (cf. Roscher's insistence in his preface that a historian like Thucydides can only be born, not educated), but for the most part their engagement with the past simply bolsters their own sense of superiority, just as the universal historian now finds traces of himself in primeval slime, congratulates himself on being capable of tracing such a course of development, and thinks of himself as nature perfected. ${ }^{35}$

'Overproud European of the nineteenth century, you are raving!' ${ }^{36}$ Such historiography is not a perfection of Thucydides' work, but the destruction of it; it has none of his understanding of the true nature of reality and the human thing, but generates only banal truisms and the belief that the past should be studied only by someone with no emotional connection to it will do nothing to save humanity from an excess of history.

What is needed instead above all is a great artistic power, a creative overview, a loving immersion in the empirical data, further development of given types - and of course objectivity is also required, but as a positive quality. ${ }^{37}$

\section{Confronting Ancient and Modern Historiography}

Nietzsche had little interest in 'reconciling' ancient and modern conceptions of and responses to history. On the contrary, he constantly emphasised the differences between them, above all at the cultural level, and invariably to the benefit of the ancients. As he remarked at the end of the Introduction to his essay,

I do not know what meaning classical studies would have in our time if not that of working in their untimeliness - that is to say, against our time and thereby on our time and, let us hope, for the benefit of a time to come. ${ }^{38}$

The different modern approaches to historiography are implicitly contrasted with a true, life-affirming historiography that does not merely draw on the past but

35 Roscher 1842, xi. Nietzsche 1874, 312-13.

36 Nietzsche 1874, 313.

37 Ibid., 292.

38 Ibid., 247. 
helps people overcome it and remove its power over them - a historiography that bears a significant resemblance to that of Thucydides. The dominance of modern culture by an unbridled sense for history is explicitly contrasted with the ability of the Greeks to remain true to themselves despite their invention of history as a form of knowledge. Above all, Nietzsche decried the attempts of the moderns to present themselves as the heirs or culmination of Thucydidean understanding, as the perfecters of historiography, where in fact for all their reverence they had radically misunderstood its true nature, and so would be incapable of echoing its achievements.

Thucydides assumed the existence of 'the human thing' as the source of a basic continuity or similarity between past, present and future, such that true knowledge of the former can illuminate and serve other times. Nietzsche for the most part insisted on discontinuity and untimeliness as the basis of understanding, but this was presented largely in opposition to the universalising claims of nineteenth-century knowledge. He shared a sense with the Greeks - or at least claimed to identify this already in classical Greece - of the timeless nature of 'human things' as an endless succession of injustice and violence, with no justificatory meaning beyond the fact that this is how life is; and this had the effect of establishing Thucydides, at least for his own purposes, as a model for the historiography of the future that radically contrasted with the way he was understood by contemporary historians.

\section{Bibliography}

Emden, Christian J. (2008), Friedrich Nietzsche and the Politics of History, Cambridge.

Girard, Jules (1860), Essai sur Thucydide, Paris.

Greenwood, Emily (2006), Thucydides and the Shaping of History, London.

Hennis, Wilhelm (2003), Max Weber und Thukydides: Nachträge zur Biographie des Werks, Tübingen.

Morley, Neville (2012), 'Thucydides, history and historicism in Wilhelm Roscher', in Katherine Harloe/Neville Morley (eds), Thucydides and the Modern world: reception, reinterpretation and influence from the Renaissance to the present, Cambridge, 115-39.

Morley, Neville (2014), Thucydides and the Idea of History, London.

Morley, Neville (2018), 'Thucydides: the origins of political realism?', in Myles Hollingsworth/ Robert Schuett (eds), The Edinburgh Companion to Political Realism, Edinburgh, 111-123.

Muhlack, Ulrich (2011), 'Herodotus and Thucydides in the view of nineteenth-century German historians', in Alexandra Lianeri (ed.), The Western Time of Ancient History: historiographical encounters with the Greek and Roman pasts, Cambridge, 179-209.

Murari Pires, Francisco (2006), 'Thucydidean modernities', in Antonios Rengakos/Antonis Tsakmakis (eds), Brill's Companion to Thucydides, Leiden, 811-37. 
Nietzsche, Friedrich (1874), 'Vom Nutzen und Nachtheil der Historie für das Leben', Unzeitgemässe Betrachtungen II, in Nietzsche, Sämtliche Werke: Kritischen Studienausgabe I, eds. Giorgio Colli/Mazzino Montinari, Berlin (2nd edn 1988).

Nietzsche, Friedrich (1875), 'Wir Philologen' [unpublished notes], in: Nietzsche, Werke IV.1, eds. Giorgio Colli/Mazzino Montinari, Berlin (1967).

Nietzsche, Friedrich (1889), Götzen-Dämmerung, oder Wie man mit dem Hammer philosophirt, in: Nietzsche, Sämtliche Werke: Kritischen Studienausgabe Vl, eds. Giorgio Colli/Mazzino Montinari, Berlin (1988).

Porter, James I. (2000), Nietzsche and the Philology of the Future, Stanford.

Roscher, Wilhelm (1842), Leben, Werk und Zeitalter des Thukydides, Göttingen.

Zumbrunnen, John (2002), 'Courage in the face of reality: Nietzsche's admiration for Thucydides', Polity 35, 237-63.

Zumbrunnen, John (2015), 'Realism, constructivism, and democracy in the History', in Christine Lee/Neville Morley (eds), A Handbook to the Reception of Thucydides, Malden MA, 296312. 